\title{
Liquid phase oxidation of $p$-xylene to terephthalic acid at medium-high temperatures: multiple benefits of $\mathrm{CO}_{2}$-expanded liquids
}

\author{
Xiaobin Zuo, ${ }^{a, b}$ Fenghui Niu, ${ }^{a}$ Kirk Snavely, ${ }^{a, c}$ Bala Subramaniam ${ }^{* a, c}$ and Daryle H. Busch ${ }^{* a, b}$ \\ Received 29th September 2009, Accepted 18th November 2009 \\ First published as an Advance Article on the web 15th January 2010 \\ DOI: 10.1039/b920262e
}

The $\mathrm{Co} / \mathrm{Mn} / \mathrm{Br}$ catalyzed oxidation of $p$-xylene to terephthalic acid (TPA) is demonstrated in $\mathrm{CO}_{2}$-expanded solvents at temperatures lower than those of the traditional Mid-Century (MC) process. As compared with the traditional air $\left(\mathrm{N}_{2} / \mathrm{O}_{2}\right)$ oxidation system, the reaction with $\mathrm{CO}_{2} / \mathrm{O}_{2}$ mixture at $160^{\circ} \mathrm{C}$ and using an additional inert gas $\left(\mathrm{N}_{2}\right.$ or $\left.\mathrm{CO}_{2}\right)$ pressure of 100 bar increases both the yield of TPA and the purity of solid TPA via a more efficient conversion of the intermediates, 4-carboxybenzaldehyde and $p$-toluic acid. At the same time, the amount of yellow colored by-products in the solid TPA product is also lessened, as determined by spectroscopic analysis. Equally important, the decomposition or burning of the solvent, acetic acid, monitored in terms of the yield of the gaseous products, $\mathrm{CO}$ and $\mathrm{CO}_{2}$, is reduced by $c a .20 \%$ based on labeled $\mathrm{CO}_{2}$ experiments. These findings broaden the versatility of this new class of reaction media in homogeneous catalytic oxidations by maximizing the utilization of feedstock carbon for desired products while simultaneously reducing carbon emissions.

\section{Introduction}

The Mid-Century (MC) process is well known for the production of terephthalic acid (TPA), a very important intermediate in the synthesis of polyethylene terephthalate and related polymers that can be fabricated into excellent fibers, resins and films. ${ }^{1,2}$ In this process, $p$-xylene is oxidized on a large scale by air at 180 $225^{\circ} \mathrm{C}$ and $15-30$ bar in the presence of a catalyst composed of cobalt acetate, manganese acetate and hydrogen bromide. The optimized yield of TPA is greater than $95 \%$, along with excellent product purity as shown by various analytical techniques. ${ }^{3}$ This process, despite successful on-stream operation for over 50 years, has the following distinct disadvantages. (1) High temperature operation decreases the solubility of $\mathrm{O}_{2}$, while increasing solvent and product destruction and causing safety concerns. (2) Air is used as the primary oxidant instead of pure $\mathrm{O}_{2}$ for safety reasons. This produces large amounts of contaminated vent gas and the abundant unreacted $\mathrm{N}_{2}$ must be cleansed before venting into the environment. (3) The combination of corrosive bromide as a catalyst component and a high operating temperature requires the use of highly resistant but expensive titanium reactors. A recent breakthrough made by Poliakoff et al. ${ }^{4}$ Savage et al. ${ }^{5}$ and Fulton et al. ${ }^{6}$ has shown that this reaction can be effectively catalyzed by $\mathrm{MnBr}_{2}$ with pure $\mathrm{O}_{2}$ in a new reaction mediumhigh temperature and supercritical water, thus circumventing the use of acetic acid. However, the scope of such reaction systems is

${ }^{a}$ Center for Environmentally Beneficial Catalysis, University of Kansas, Lawrence, KS 66047, USA. E-mail: bsubramaniam@ku.edu;

Fax: 785-864-6051; Tel: 785-864-2903

${ }^{b}$ Department of Chemistry, University of Kansas, Lawrence, KS, 66047,

USA.E-mail: busch@ku.edu; Fax: 785-864-6051;Tel: 785-864-1644

'Department of Chemical and Petroleum Engineering, University of

Kansas, Lawrence, KS 66045, USA limited by the even harsher reaction conditions $\left(T=300-400^{\circ} \mathrm{C}\right.$, $P>200$ bar).

$\mathrm{CO}_{2}$-based media have attracted much attention in recent years because they provide the possibility of using pure $\mathrm{O}_{2}$ under safe conditions while overcoming most of the aforementioned limitations of air oxidation systems, as follows. ${ }^{7-10}$ (1) The use of $\mathrm{CO}_{2}$ in a mixed solvent increases both the $\mathrm{O}_{2}$ solubility and the mass transport of the reactants in the liquid phase, the former because of the significant solubility of $\mathrm{O}_{2}$ in liquid $\mathrm{CO}_{2}$ and the latter because of improved diffusivities in $\mathrm{CO}_{2}$ media. ${ }^{11}$ This is especially the case in carbon dioxide expanded liquids (CXLs). A rule of thumb is the nearly ten fold increase in oxygen solubility when the volume of solvent is expanded by a factor of two, depending on the properties of solvent. (2) The presence of $\mathrm{CO}_{2}$ in the vapor phase reduces flammability hazards because of the great abundance of inert $\mathrm{CO}_{2}$ and its large heat capacity. (3) Replacing the $\mathrm{N}_{2}$ from air with a much greater amount of $\mathrm{CO}_{2}$ eliminates the contaminated vent gas because the $\mathrm{CO}_{2}$ is more easily separated and recycled in the oxidation process. However, this is counterbalanced by the required separation of $\mathrm{O}_{2}$ from $\mathrm{N}_{2}$.

The first successful application of CXLs in oxidation reactions was reported in 2002. ${ }^{12,13}$ The Co(salen) catalyzed oxidation of 2,6-di-tert-butyl phenol to 2,6-di-tert-butyl-1,4-benzoquinone in $\mathrm{CO}_{2}$-expanded acetonitrile was 1-2 orders of magnitude more active than in either the neat organic solvent or supercritical $\mathrm{CO}_{2}$. We recently described the synergistic effect of co-catalyst zirconium and promoter ketone in the oxidation of toluene from 50 to $100{ }^{\circ} \mathrm{C} .{ }^{14}$ It was found that $\mathrm{CO}_{2}$ has a strong activation effect on the reaction, especially by shortening the induction period. Under certain conditions, the $\mathrm{Co} / \mathrm{Zr}(\mathrm{acac})_{4}$ catalyzed oxidation did not work at all with $\mathrm{N}_{2} / \mathrm{O}_{2}$ but proceeded effectively with $\mathrm{CO}_{2} / \mathrm{O}_{2}$, affording high yields of benzoic acid. In 
this work, we extend the $\mathrm{CO}_{2}$ effect to this important industrial TPA process, which is extremely challenging because of much higher temperatures and the complexity of intermediates. More specifically, the TPA precipitates during the reaction, occluding with it 4-carboxybenzaldehyde and other by-products. In addition, the decomposition, or burning of solvent, is more significant at higher temperatures. To this end, in the present work, we first measured the expansion of acetic acid, containing dissolved catalysts and substrate, by dense $\mathrm{CO}_{2}$. Then, based on these results, we investigated the semi-continuous oxidation of $p$-xylene at lower temperatures as compared with the MC process for a more significant $\mathrm{CO}_{2}$ effect, with the expectation that CXLs could bring about some specific advantages for product selectivity and purity in this complex reaction system.

\section{Experimental}

\subsection{Materials}

All the catalysts, additives, substrates and solvents were commercially available and used without further treatment. Industrial grade ( $\geq 99.9 \%$ purity, $<32 \mathrm{ppm} \mathrm{H}_{2} \mathrm{O},<20 \mathrm{ppm}$ THC) liquid $\mathrm{CO}_{2}$ and ultra high purity grade oxygen were purchased from Linweld. Isotopic gas ${ }^{13} \mathrm{CO}_{2}\left(99.5\right.$ atom $\left.\%{ }^{13} \mathrm{C}\right)$ was purchased from Aldrich Chemical Co., Inc.

\subsection{Volumetric expansion of acetic acid + catalyst mixtures by dense $\mathrm{CO}_{2}$}

The volumetric expansion by $\mathrm{CO}_{2}$ of acetic acid containing dissolved catalysts was measured in a high-pressure Jerguson view cell that was placed in a high temperature oven (Yamato DKN-400, part of a Cambridge Viscosity ViscoPro 2000 system, Fig. 1). For these expansion studies, a measured volume of acetic acid containing a known amount of catalysts was loaded into the view cell and heated to the experimental temperature, which was followed by the addition of 20 bar $\mathrm{N}_{2}$ as the substitute for $\mathrm{O}_{2}$. Then $\mathrm{CO}_{2}$ was gradually introduced into the cell until an expansion ratio $\left(\Delta V / V_{\mathrm{o}}\right.$, eqn 1$)$ of $c a .1 .0$ was obtained.

$$
\frac{\Delta V}{V_{o}}=\frac{V(P)-V_{o}\left(P_{o}\right)}{V_{o}\left(P_{o}\right)}
$$

where $P_{\mathrm{o}}$ refers to ambient pressure from which the solution is expanded; and $P$ refers to cell pressure at $\mathrm{CO}_{2}$ expansion conditions.

\subsection{Oxidation experiments and product analysis}

2.3.1 Oxidation experiments. The semi-continuous oxidation of $p$-xylene to terephthalic acid was studied in a $50 \mathrm{~mL}$, stirred, titanium Parr reactor (Fig. 2). Typically, $\mathrm{N}_{2}$ or $\mathrm{CO}_{2}$ was first added to the reactor containing the solvent and catalysts and heated to the reaction temperature; then $\mathrm{O}_{2}$ was added until the selected final pressure was reached. $p$-Xylene was subsequently pumped into the reactor at a pre-defined rate $(0.08 \mathrm{~mL} / \mathrm{min})$ to initiate the reaction. The total reactor pressure was maintained constant by continuously supplying fresh $\mathrm{O}_{2}$ to compensate for the oxygen consumed in the reaction.

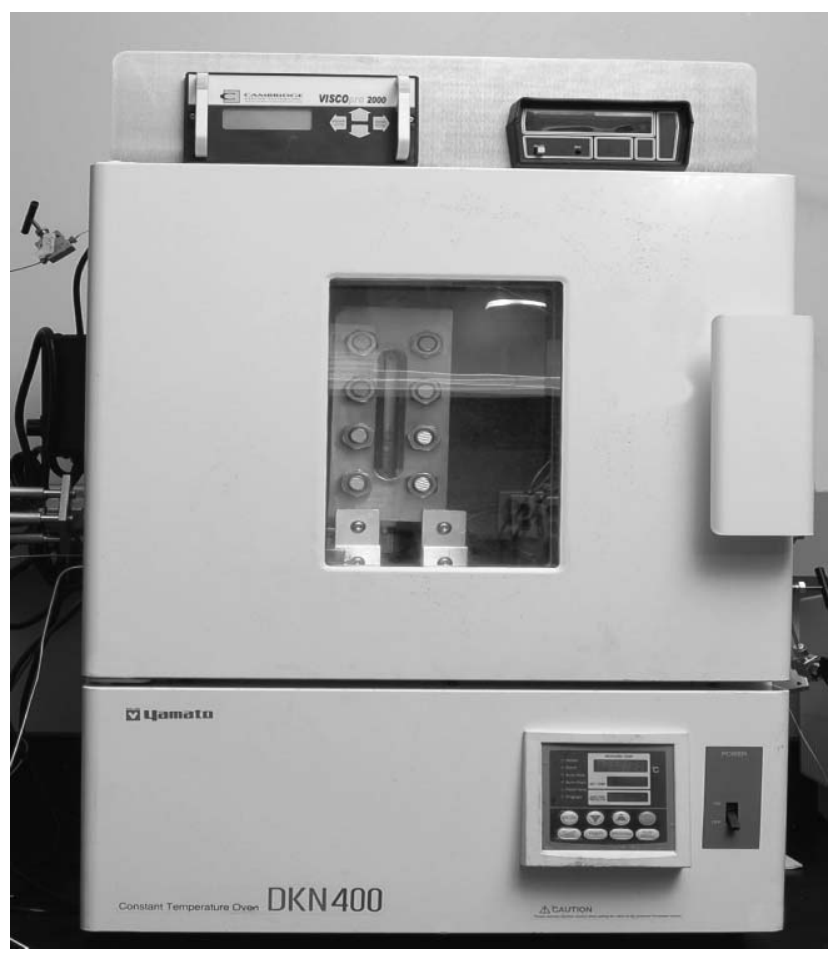

Fig. 1 Jerguson cell in oven for high temperature studies of CXLs.

2.3.2 Product analysis. After the reaction, the reaction mixture was cooled to room temperature and then treated as follows:

The gas mixture was analyzed by GC (Shin Carbon ST $100 / 120$ mesh) to determine the yield of $\mathrm{CO}$ and $\mathrm{CO}_{2}$ produced by solvent burning. For isotopic experiments, the ${ }^{12} \mathrm{CO}_{2} /{ }^{13} \mathrm{CO}_{2}$ ratio was measured by mass spectrometry.

The insoluble terephthalic acid was separated from the liquid mixture by filtration and the solid was washed with methanol to remove most of the soluble impurities. The resulting white solid was dried at $100{ }^{\circ} \mathrm{C}$ for $2 \mathrm{hrs}$ to remove absorbed solvent, after which a $10 \mathrm{mg}$ sample was dissolved in $50 \mathrm{~mL}$ of methanol by sonication and analyzed by HPLC (C18 ODS-2 column). The reactor was washed with methanol and DMF to scavenge the residual TPA solid, which was combined with the filtrate that was retained after isolation of the solid TPA and analyzed by HPLC to determine the composition of liquids. The yields of products were based on the sums of those determined for the solid and liquid components.

The presence of yellow colored by-products in solid TPA was determined from optical density measurements using a UVVis spectrometer at $340 \mathrm{~nm} .{ }^{15}$ Typically, $0.3 \mathrm{~g}$ solid sample was dissolved in $5 \mathrm{~mL} 4 \mathrm{~N} \mathrm{NH} \mathrm{NH}_{4} \mathrm{OH}$. The optical density was calculated as in eqn 2 :

$$
O D_{\lambda}=A_{\lambda} / L
$$

where $A_{\lambda}$ refers to the absorbance at wavelength $\lambda(\mathrm{nm})$; and $L$ refers to the distance $(\mathrm{cm})$ that light travels through the sample.

\subsection{Safety}

The amount of substrate used in the reaction studies was such that the maximum adiabatic temperature rise for total 


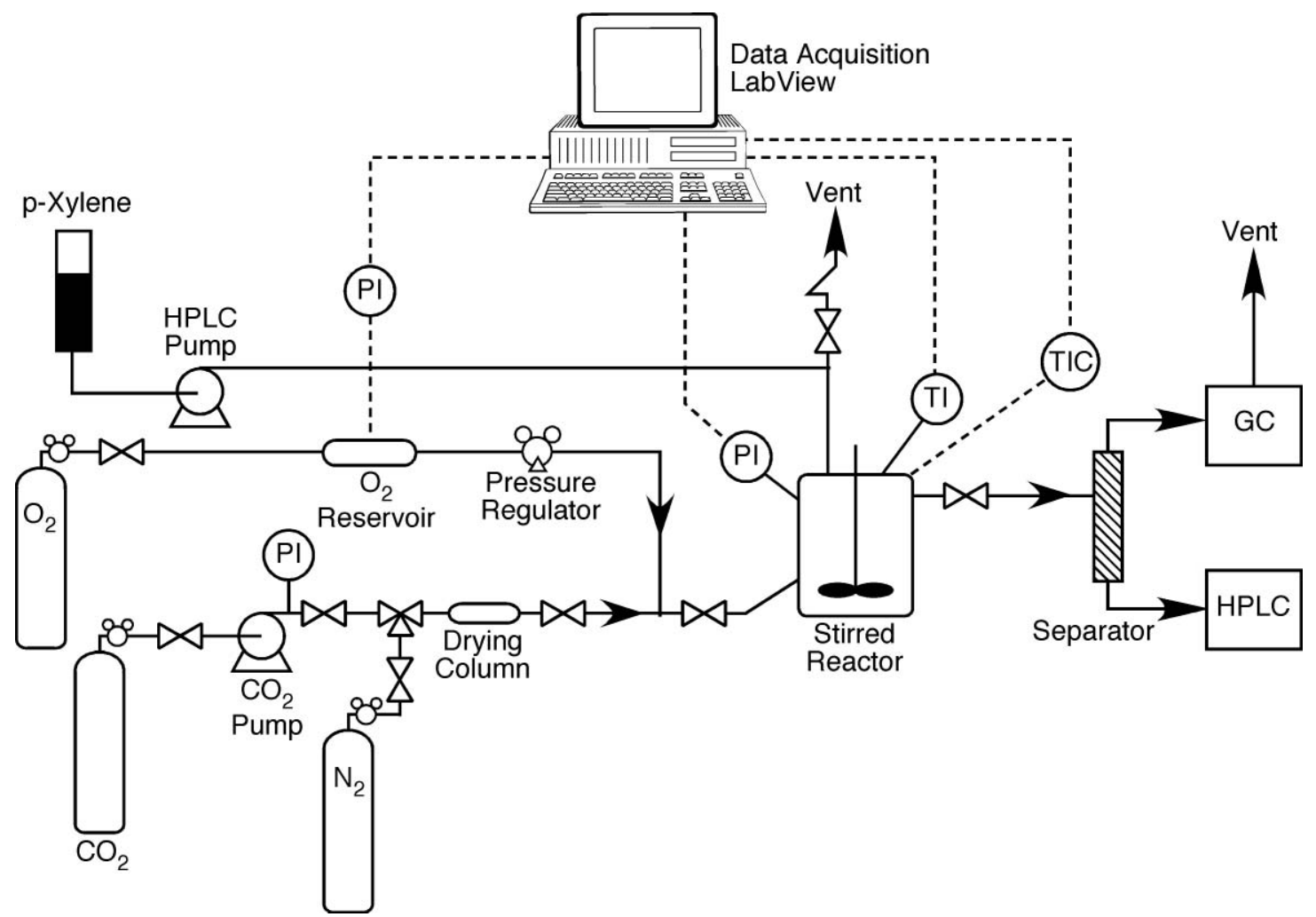

Fig. 2 Schematic diagram of semi-continuous oxidation $p$-xylene to terephthalic acid.

combustion of the substrate (taking into account the heat capacities of the reaction mixture and the solid reactor) was $25{ }^{\circ} \mathrm{C}$. The actual temperature rise observed during reactions was a few ${ }^{\circ} \mathrm{C}$, at most. In addition, the reactor was equipped with a safety release valve that exhausts the reactor contents safely to the building vent by means of a rupture disk in the event the set safe pressure (200 bar) is exceeded.

\section{Results and discussion}

\section{1 $\mathrm{CO}_{2}$ expansion measurements at 80 and $120{ }^{\circ} \mathrm{C}$}

Since supercritical $\mathrm{CO}_{2}\left(T_{\mathrm{C}}=31{ }^{\circ} \mathrm{C}\right)$ expands liquids most effectively at temperatures up to 1.2 times the absolute critical temperature, our previous work was focused on reactions performed at $60{ }^{\circ} \mathrm{C}$ or less wherein it was possible to measure the solvent expansion in a water bath. ${ }^{12,16,17}$ Here, to measure the catalyst solubility in $\mathrm{CO}_{2}$-expanded solvent at much higher temperatures, in experiments that are the first of their kind for $p$-xylene oxidation, we placed the high pressure Jerguson view cell in a high temperature oven that was originally designed for viscosity measurement (Fig. 1). Though the oven temperature can be maintained as high as $200{ }^{\circ} \mathrm{C}$, these studies did not go beyond $120^{\circ} \mathrm{C}$ because of the corroding capability of acetic acid and hydrogen bromide toward the stainless steel Jerguson cell.

The catalyst solution, containing $60 \mathrm{mM}$ cobalt acetate, $1.8 \mathrm{mM}$ manganese acetate and $60 \mathrm{mM}$ hydrogen bromide in acetic acid, has a slight pink tint at room temperature (Fig. 3a) which turns blue when heated to $120^{\circ} \mathrm{C}$ (Fig. 3b). The solution

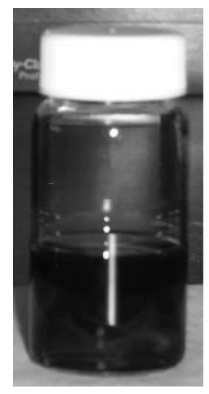

(a)

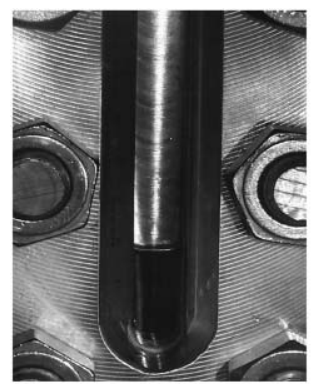

(b)

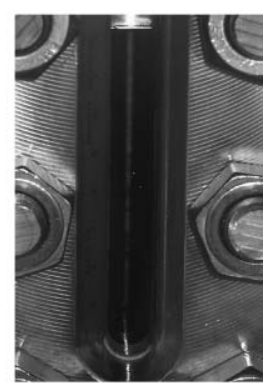

(c)
Fig. 3 Catalyst solution and its expansion with increasing $\mathrm{CO}_{2}$ pressure. (a) room temperature, (b) $120{ }^{\circ} \mathrm{C}$ with 20 bar $\mathrm{N}_{2}$ and 18 bar $\mathrm{CO}_{2}$, (c) $120^{\circ} \mathrm{C}$ with 20 bar $\mathrm{N}_{2}$ and 159 bar $\mathrm{CO}_{2} ;[\mathrm{Co}]=60 \mathrm{mM}$, [Mn] $=$ $1.8 \mathrm{mM},[\mathrm{Br}]=60 \mathrm{mM}$ prior to the expansion.

is expanded significantly at the much higher $\mathrm{CO}_{2}$ pressure of $c a$. 160 bar (Fig. 3c).

Fig. 4 a shows the dependence of the expansion ratio on $\mathrm{CO}_{2}$ pressure at $120^{\circ} \mathrm{C}$. The expansion ratio increases gradually and reaches a value of 0.85 when $\mathrm{CO}_{2}$ partial pressure is elevated to 160 bar (total pressure 180 bar). Accordingly, the concentrations of cobalt, manganese and bromide are diluted to $33 \mathrm{mM}$, $1.0 \mathrm{mM}$ and $33 \mathrm{mM}$, respectively. It is noteworthy that no catalyst precipitates during the $\mathrm{CO}_{2}$ expansion. This implies the possibility of replacing up to at least $50 \mathrm{vol} \%$ of the organic solvent by $\mathrm{CO}_{2}$ while maintaining the catalyst in solution.

Fig. 4b shows the expansion result at $80{ }^{\circ} \mathrm{C}$. As compared with $120{ }^{\circ} \mathrm{C}$, the expansion ratio at $80{ }^{\circ} \mathrm{C}$ is much higher, 

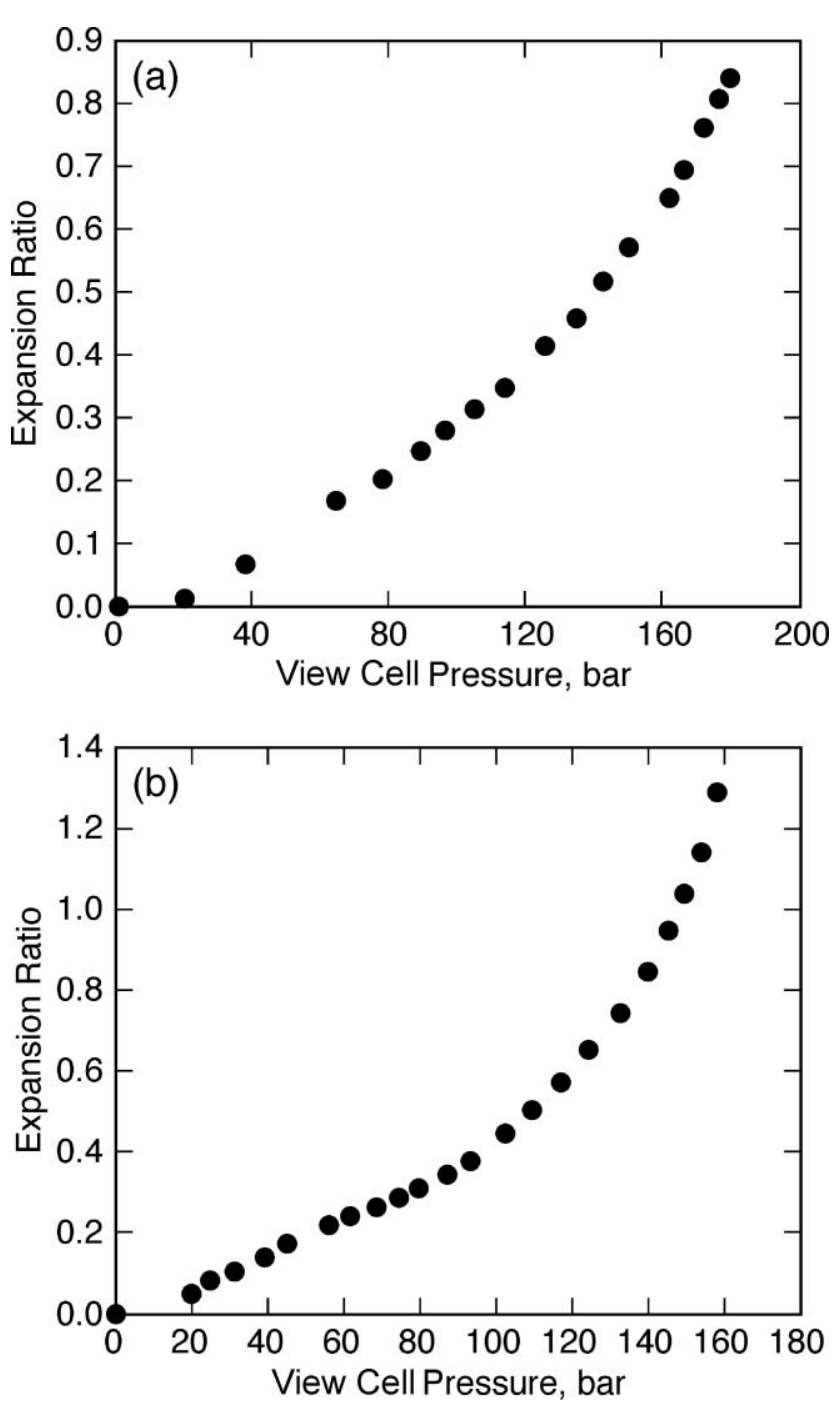

Fig. 4 Volumetric expansion of acetic acid by $\mathrm{CO}_{2}$ with $\mathrm{Co} / \mathrm{Mn} / \mathrm{Br}$ catalysts. (a) $T=120{ }^{\circ} \mathrm{C}$, (b) $T=80{ }^{\circ} \mathrm{C}$; [Co] $=60 \mathrm{mM},[\mathrm{Mn}]=$ $1.8 \mathrm{mM},[\mathrm{Br}]=60 \mathrm{mM}$ prior to the expansion.

reaching an approximate value of one (1) when the $\mathrm{CO}_{2}$ partial pressure is 130 bar. However, the catalysts precipitate upon further increases in $\mathrm{CO}_{2}$ pressure; e.g., approaching 140 bar.
Further, the expansion behavior is different from that at $120^{\circ} \mathrm{C}$, displaying a sharp enhancement when $\mathrm{CO}_{2}$ pressure exceeds 100 bar. This is attributed to the higher compressibility of the $\mathrm{CO}_{2}$ with pressure at the lower temperature resulting in enhanced dissolution into and volumetric expansion of the liquid phase.

\subsection{Semi-continuous oxidation of $p$-xylene}

3.2.1 Reactions in $\mathrm{CO}_{2}$-expanded acetic acid: $\mathrm{CO}_{2}$ vs. $\mathrm{N}_{2}$ as inert gas. The $\mathrm{CO}_{2}$ effect on oxidation of $p$-xylene has been reported by Yoo et al. ${ }^{18,19,20}$ However, only a modest increase in the yield of TPA was achieved because of the high reaction temperature $\left(>190^{\circ} \mathrm{C}\right)$ and low $\mathrm{CO}_{2}$ partial pressure $(<14$ bar $)$. In these reactions, the solvents were not expanded; i.e., $\mathrm{CO}_{2}$ was not a significant component of the solvent.

We started the reaction at $80{ }^{\circ} \mathrm{C}$, much lower than the temperature used in the $p$-xylene oxidation process, to ensure a substantial expansion at relatively low $\mathrm{CO}_{2}$ pressure. Accordingly, a preliminary reaction was performed at a $\mathrm{CO}_{2}$ pressure of 111 bar, where the expansion ratio was 0.75 . However, as shown in Table 1 , the process was very sluggish, generating only $1 \%$ TPA after $22 \mathrm{~h}$ (Entry 1). We rationalize this result on the basis of our understanding that the temperature was too low to overcome the activation energy of the reaction.

In the next reaction, the temperature was raised to $120{ }^{\circ} \mathrm{C}$ to accelerate the oxidation. As shown in Table 1, under a low inert gas pressure of 45 bar, there is no obvious difference between $\mathrm{N}_{2}$ and $\mathrm{CO}_{2}$ in the yield of TPA ( $c a .80 \%$ in $0.5 \mathrm{~h}$ ) as well as those of the by-products 4-carboxybenzaldehyde (4-CBA) and $p$-toluic acid (PTA) (Entries 2 and 3). HPLC analysis of the solid TPA quantified the expected major impurities, 4-CBA and PTA. As compared with $p$-xylene, PTA is much less reactive than the starting material due to the deactivating effect of the electron withdrawing carboxyl group. During the reaction, 4-CBA tends to co-precipitate with TPA and is very difficult to remove. Since 4-CBA is an inhibitor in the subsequent polymerization reaction, its concentration should be kept as low as possible. In addition, the solid also contains trace amounts of yellow colored by-products such as the derivatives of fluorenone and anthraquinone that can affect the quality of polymers. ${ }^{21}$ The presence of these compounds is detected by the optical density at $340 \mathrm{~nm} .{ }^{15}$ The lower that optical density, the lesser the amounts

Table 1 Oxidation of $p$-xylene in $\mathrm{CO}_{2}$ expanded acetic acid ${ }^{a}$

\begin{tabular}{|c|c|c|c|c|c|c|c|c|c|c|c|c|c|}
\hline Entry & Inert gas & $\begin{array}{l}\mathrm{P} \text { inert } \\
\text { (bar) }\end{array}$ & $\mathrm{PO}_{2}$ (bar) & $\mathrm{T}\left({ }^{\circ} \mathrm{C}\right)$ & $\begin{array}{l}\text { Expansion Ratio } \\
\left(\Delta \mathrm{V} / \mathrm{V}_{0}\right)\end{array}$ & $\begin{array}{l}\text { Reaction } \\
\text { Time (h) }\end{array}$ & $\begin{array}{l}Y_{\text {TPA }} \\
(\%)\end{array}$ & $\begin{array}{l}Y_{4-\mathrm{CBA}} \\
(\%)\end{array}$ & $\begin{array}{l}Y_{\text {PTA }} \\
(\%)\end{array}$ & $\begin{array}{l}\operatorname{TPA}(\mathrm{s})^{b} \\
\left(\mathrm{wt}^{0} \%\right)\end{array}$ & $\begin{array}{l}\text { 4-CBA } \\
(\mathrm{s})^{c} \mathrm{ppm}\end{array}$ & $\mathrm{OD}_{340}$ & $\begin{array}{l}\mathrm{CO} / \mathrm{p}-\mathrm{x} \\
(\mathrm{mol} / \mathrm{mol})\end{array}$ \\
\hline 1 & $\mathrm{CO}_{2}$ & 111 & 28 & 80 & 0.75 & 22 & 1.0 & 0.5 & 15.5 & - & 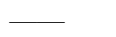 & - & $\longrightarrow$ \\
\hline 2 & $\mathrm{~N}_{2}$ & 45 & 45 & 120 & 0 & 0.5 & 78.6 & 10.5 & 4.7 & 85.7 & 104000 & 0.69 & 0.011 \\
\hline 3 & $\mathrm{CO}_{2}$ & 45 & 45 & 120 & 0.17 & 0.5 & 79.0 & 10.0 & 4.3 & 86.2 & 101000 & 0.58 & 0.0065 \\
\hline 4 & $\mathrm{CO}_{2}$ & 107 & 45 & 120 & 0.42 & 2.0 & 77.6 & 6.9 & 4.2 & 89.1 & 72000 & 0.66 & 0 \\
\hline 5 & $\mathrm{CO}_{2}$ & 145 & 20 & 120 & 0.69 & 2.0 & 73.4 & 8.6 & 5.7 & 85.4 & 94000 & 1.30 & 0 \\
\hline 6 & $\mathrm{~N}_{2}$ & 30 & 30 & 160 & 0 & 0.5 & 94.6 & 1.3 & 0.7 & 98.4 & 11700 & 0.086 & 0.040 \\
\hline 7 & $\mathrm{CO}_{2}$ & 30 & 30 & 160 & 0 & 0.5 & 94.6 & 1.3 & 0.7 & 98.4 & 11500 & 0.087 & 0.038 \\
\hline 8 & $\mathrm{~N}_{2}$ & 100 & 30 & 160 & 0 & 0.5 & 93.8 & 1.2 & 0.7 & 98.5 & 10500 & 0.069 & 0.035 \\
\hline 9 & $\mathrm{CO}_{2}$ & 100 & 30 & 160 & 0.15 & 0.5 & 95.1 & 0.8 & 0.6 & 99.1 & 6400 & 0.063 & 0.019 \\
\hline
\end{tabular}

${ }^{a}$ Reaction conditions: $[\mathrm{Co}]=33 \mathrm{mM},[\mathrm{Mn}]=1.0 \mathrm{mM},[\mathrm{Br}]=33 \mathrm{mM}, \mathrm{V}_{\mathrm{L}}$ (volume of liquid phase) $=35 \mathrm{~mL}$ (with or without $\mathrm{CO}_{2}$ expansion), $1.6 \mathrm{~mL}$ $p$-xylene added at $0.08 \mathrm{~mL} / \mathrm{min}, \mathrm{n}$ (stirrer speed) $=1200 \mathrm{rpm} .{ }^{b} \mathrm{TPA}$ in dry isolated solid. ${ }^{c}$ 4-CBA in dry isolated solid. The conversion of $p$-xylene is above $99 \%$ in all the reactions except entry 1 . In addition to 4-CBA and PTA, a few other byproducts were detected in small amounts during the HPLC analysis. These compounds were not identified. 
of these yellow colored by-products. As shown in Table 1, when the inert gas pressure is 45 bar, the amount of 4-CBA in the TPA solid is quite similar for $\mathrm{N}_{2}$ and $\mathrm{CO}_{2}$, whereas the optical density is lower for $\mathrm{CO}_{2}$. As $\mathrm{CO}_{2}$ pressure is increased to $107 \mathrm{bar}$, the corresponding expansion ratio is 0.42 , and the yield of TPA approaches $80 \%$ (Entry 4), however, a relatively long reaction time of $2 \mathrm{~h}$ is required. Further increase of $\mathrm{CO}_{2}$ pressure to 145 bar (expansion ratio $=0.69$ ) and decrease of $\mathrm{O}_{2}$ pressure to 21 bar produces a lower yield of TPA (Entry 5). On the other hand, the optical density is much higher, which indicates higher concentrations of yellow colored by-products. The reason for this phenomenon remains unclear. Based on HPLC analysis, the yields of TPA and the common by-products (4-CBA and PTA) at a $\mathrm{CO}_{2}$ pressure of 145 bar are $73.4 \%, 8.6 \%$ and $5.7 \%$ respectively (Table 1 , entry 5). Since the $p$-xylene conversion is above $99 \%$, the unknown by-products (peaks seen in the HPLC but not positively identified) account for more than $10 \%$ of the $p$-xylene converted. The TPA precipitate recovered from the reaction mixture has a very dense yellow color (the optical density is much higher as compared with that of the TPA solid produced at lower $\mathrm{CO}_{2}$ pressure), which indicates significant formation of derivatives of fluorenone and anthraquinone. Based on these results, it is reasonable to assume that at $120^{\circ} \mathrm{C}$, regardless of the use of CXLs at various $\mathrm{O}_{2}$ partial pressures, the kinetic rates of the consecutive oxidation reactions of $p$-xylene to yield TPA are not fast enough to avoid the intermediate oxidation products and the other byproducts that adversely affect the TPA purity.

At $120{ }^{\circ} \mathrm{C}$, the only positive effect of $\mathrm{CO}_{2}$-based media is therefore the lower yield of the gaseous product $\mathrm{CO}$, which falls to zero when $\mathrm{CO}_{2}$ pressure is above 100 bar. This suggests that $\mathrm{CO}_{2}$ might inhibit solvent burning. However, at this point we have not determined the yield of the second gaseous product, $\mathrm{CO}_{2}$ produced by burning, although such a differentiation should be possible using labeled $\mathrm{CO}_{2}$ (vide infra).

The catalytic performance is greatly improved as the temperature is further increased to $160{ }^{\circ} \mathrm{C}$, where two sets of reactions were carried out to provide additional comparisons between the behaviors in $\mathrm{N}_{2}$ and $\mathrm{CO}_{2}$ at even higher yields of TPA. As shown in Table 1 , under a low inert gas $\left(\mathrm{N}_{2}\right.$ or $\left.\mathrm{CO}_{2}\right)$ pressure of 30 bar, the reaction results are almost identical for $\mathrm{N}_{2}$ and $\mathrm{CO}_{2}$ (Entries 6 and 7). When $\mathrm{N}_{2}$ pressure is increased to 100 bar, there is little difference in the reaction results except a modest decrease of optical density (Entries 6 and 8). The results are completely different, however, when $\mathrm{CO}_{2}$ pressure is increased to 100 bar. The expansion ratio is estimated to be 0.15 , as extrapolated from the expansion data for $80-120^{\circ} \mathrm{C}$. In addition to a minor enhancement in TPA yield as compared to that for 100 bar of $\mathrm{N}_{2}$, the oxidation process in CXL benefits a great deal in several aspects (Entries 6-9). (1) The yield of by-products, especially that of 4-CBA, is markedly decreased. This indicates the more complete oxidation of the intermediates to TPA in $\mathrm{CO}_{2}$-expanded solvent that is possibly associated with increased oxygen availability. (2) The purity of solid TPA is enhanced by the reduction of 4-CBA concentration from $11000 \mathrm{ppm}$ to $6400 \mathrm{ppm}$. (3) The optical density is the lowest among the four sets of reaction conditions. (4) The yield of CO is significantly decreased; i.e., by about $50 \%$. In general, the concentration of 4-CBA in TPA solid is inversely related to the burning of solvent, i.e. lower 4-CBA concentrations are always accompanied by higher burning rate. ${ }^{22}$ In sharp contrast, our finding demonstrates that it is possible to reduce the production of both these solid and gaseous by-products simultaneously by employing high pressure $\mathrm{CO}_{2}$. In conclusion, a multi-beneficial effect of CXL has been exhibited in the $\mathrm{Co} / \mathrm{Mn} / \mathrm{Br}$ catalyzed oxidation of $p$-xylene to terephthalic acid.

\subsubsection{Reaction optimization at temperatures less than $180^{\circ} \mathrm{C}$.} As reported in the literature, two methods have commonly been used to adjust the catalyst to reduced reaction temperatures while maintaining TPA yields that are close to those of the current optimized industrial process: (1) The considerable increase of cobalt and bromide concentrations while decreasing the manganese concentration. ${ }^{23}$ The mole ratio of cobalt to manganese can be as high as 100 to avoid the precipitation of manganese in order to avoid grey or black TPA products. ${ }^{24}$ (2) The addition of other transition metals as co-catalysts, ${ }^{25-28}$ among which zirconium is the most efficient one that can further lower the reaction temperature to about $100{ }^{\circ} \mathrm{C}$. Due to the lack of systematic data in these related systems, we have optimized the reactions in the temperature range $120-170{ }^{\circ} \mathrm{C}$, with emphasis placed on the influence of cobalt and manganese concentrations and effect of zirconium on the yield of TPA, solid TPA purity, optical density at $340 \mathrm{~nm}$ and yield of CO. For ease of operation and comparison purposes, the pressure of $\mathrm{CO}_{2}$ was chosen as 30 bar. As a superior flame inhibitor to nitrogen, the use of $\mathrm{CO}_{2}$ makes it possible to run the reactions safely with an equimolar amount of oxygen in the gas phase. ${ }^{29}$ Thus, 30 bar $\mathrm{O}_{2}$ was introduced to ensure a large excess of oxygen over $p$-xylene.

As shown in Fig. 5a, the yield of TPA is significantly elevated by doubling the concentration of cobalt from $33 \mathrm{mM}$ to $66 \mathrm{mM}$ and adding zirconium, in the form of the acetate $(\mathrm{Zr} / \mathrm{Co}=$ 1/6) at lower temperatures. However, this promoting effect diminishes when the temperature is above $150{ }^{\circ} \mathrm{C}$. The highest TPA yield of $97.5 \%$ is achieved with the combination of cobalt and zirconium at $170^{\circ} \mathrm{C}$.

The effect on the purity of solid TPA parallels that on TPA yield. As shown in Fig. 5b, increasing the cobalt concentration and the use of zirconium enhances the purity of solid TPA, an effect that is more pronounced at lower temperatures. Also the highest purity is achieved with the combination of cobalt and zirconium at $170{ }^{\circ} \mathrm{C}$. This is not surprising because the more complete conversion of the dissolved intermediates will definitely decrease their concentration in solid TPA.

The effect on the optical density at $340 \mathrm{~nm}$ is somewhat intriguing. As shown in Fig. 5c, an increase in cobalt concentration always helps lower the yield of yellow colored by-products within the studied temperature ranges. However, the incorporation of zirconium works well only at lower temperatures. The quality of the optical density no longer benefits from zirconium when the temperature is greater than $160^{\circ} \mathrm{C}$.

The effect on the yield of $\mathrm{CO}$ is more complicated. As shown in Fig. 5 d, the production of $\mathrm{CO}$ can be inhibited by doubling the cobalt concentration and adding zirconium at temperatures below $135^{\circ} \mathrm{C}$. This might be unexpected since higher cobalt concentrations are considered to favor solvent burning. ${ }^{30}$ In contrast, there is a surge in $\mathrm{CO}$ yield when the temperature rises above $150{ }^{\circ} \mathrm{C}$, especially with the use of zirconium. 

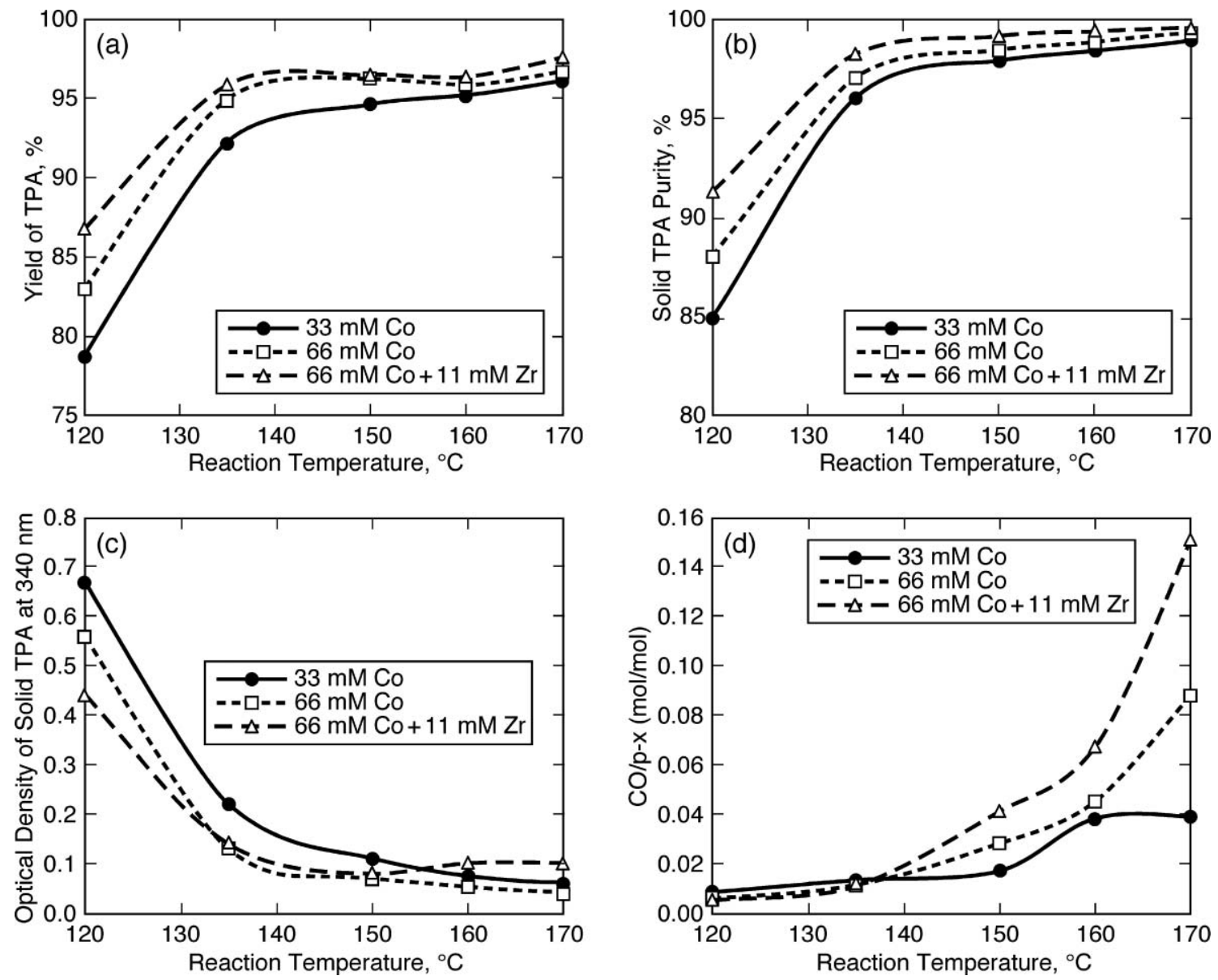

Fig. 5 Effects of cobalt concentration and zirconium on $p$-xylene oxidation. Reaction conditions: $\mathrm{PCO}_{2}=\mathrm{PO}_{2}=30 \mathrm{bar},[\mathrm{Mn}]=1.0 \mathrm{mM},[\mathrm{Br}]=$ $33 \mathrm{mM}, V_{\mathrm{L}}=35 \mathrm{~mL}, 1.6 \mathrm{~mL} p$-xylene added at $0.08 \mathrm{~mL} / \mathrm{min}, t=0.5 \mathrm{hr}, n=1200 \mathrm{rpm}$.

Fig. 6 shows the effect of manganese. The reactions were carried out with a higher cobalt concentration of $66 \mathrm{mM}$ at $170{ }^{\circ} \mathrm{C}$. No zirconium was used because of the much higher solvent burning at this temperature.

As shown in Fig. 6a and 6b, the yield of TPA and solid TPA purity decrease monotonically with the increase of manganese concentration. In the absence of manganese, the yield and purity can be as high as 96.9\% and $99.5 \%$, and these are decreased to $93.3 \%$ and $98.5 \%$ respectively when the manganese concentration is increased to $8.0 \mathrm{mM}$.

Too much manganese is also disadvantageous from the standpoint of the optical density. As shown in Fig. 6c, in the complete absence of manganese, the TPA solid has a very low optical density of 0.025 . In comparison, this value quadruples to $c a .0 .1$ when the manganese concentration is $8.0 \mathrm{mM}$.

In spite of all these negative effects, manganese still plays a crucial role. As shown in Fig. 6d, the yield of CO is decreased by ca. $30 \%$ at a very low manganese concentration of $1.0 \mathrm{mM}$. At the same time, the yield of TPA is only slightly decreased from $96.9 \%$ to $96.6 \%$. Thus, manganese is very effective in reducing solvent burning.

From the results described above, the optimized parameters for the medium-high temperature oxidation of $p$-xylene are: $[\mathrm{Co}] \geq 60 \mathrm{mM},[\mathrm{Mn}] \leq 1.0 \mathrm{mM},[\mathrm{Zr}]=0 \mathrm{mM}, T=150-160{ }^{\circ} \mathrm{C}$.
3.2.3 Effect of $\mathrm{CO}_{2}$ on solvent burning-isotopic study. Solvent burning is a very important side reaction in $p$-xylene oxidation, which accounts for a significant loss of acetic acid each year. It is estimated that $70 \%$ of acetic acid produced worldwide is used to manufacture TPA, and about $5 \%$ of this solvent is destroyed by burning. ${ }^{22,31}$ Therefore, solvent burning is a significant factor in the economics of the MC process. The burn rate is reported as the mole ratio of gaseous products, $\mathrm{CO}$ and $\mathrm{CO}_{2}$, produced to the moles of $p$-xylene added. Our previous work on the Shell catalyst $(\mathrm{Co} / \mathrm{Zr})$ suggests that $\mathrm{CO}_{2}$ might reduce solvent burning by inhibiting the $\mathrm{Co}(\mathrm{III})-$ catalyzed decarboxylation of acetic acid. ${ }^{14}$ The compelling issue is expressed in the question "is it possible to reduce solvent burning in the $\mathrm{Co} / \mathrm{Mn} / \mathrm{Br}$ catalyzed oxidation of $p$-xylene by using $\mathrm{CO}_{2}$-based media?"

For this purpose, we chose the labeled compound ${ }^{13} \mathrm{CO}_{2}$ as the inert gas. By mass spectrometry, the $\mathrm{CO}_{2}$ produced by burning can be differentiated from the $\mathrm{CO}_{2}$ added to the system by chemical reaction(s). To compare the different behavior of $\mathrm{N}_{2}$ and $\mathrm{CO}_{2}$ in solvent burning, three sets of reactions have been carried out, among which two sets are based on a lower temperature of $160{ }^{\circ} \mathrm{C}$ and a higher inert gas pressure of $45 \mathrm{bar}$, while the other set is based on a higher temperature of $191^{\circ} \mathrm{C}$ and a lower inert gas pressure of 23 bar. The $\mathrm{O}_{2}$ pressure for the latter case is controlled at 7 bar to mimic an MC process as 
Table 2 Effect of $\mathrm{CO}_{2}$ on solvent burning

\begin{tabular}{llllllll}
\hline Inert gas & $\mathrm{T}\left({ }^{\circ} \mathrm{C}\right)$ & $\mathrm{P}$ inert (bar) & $\mathrm{PO}_{2}(\mathrm{bar})$ & $\mathrm{Y}_{\mathrm{TPA}}(\%)$ & ${ }^{12} \mathrm{CO}(\mathrm{mmol})$ & ${ }^{12} \mathrm{CO}_{2}(\mathrm{mmol})$ & $\left({ }^{12} \mathrm{CO}{ }+{ }^{12} \mathrm{CO}\right) / p$-x $(\mathrm{mol} / \mathrm{mol})$ \\
\hline $\mathrm{N}_{2}$ & 160 & 45 & 45 & 94.6 & 0.52 & 1.30 & 0.14 \\
${ }^{13} \mathrm{CO}_{2}$ & 160 & 45 & 45 & 95.1 & 0.32 & 1.11 & 0.11 \\
$\mathrm{~N}_{2}$ & 160 & 45 & 12 & 94.1 & 0.37 & 0.89 & 0.095 \\
${ }^{13} \mathrm{CO}_{2}$ & 160 & 45 & 12 & 94.3 & 0.23 & 0.76 & 0.075 \\
$\mathrm{~N}_{2}$ & 191 & 23 & 7 & 84.7 & 0.45 & 0.68 & 0.085 \\
${ }^{13} \mathrm{CO}_{2}$ & 191 & 23 & 7 & 94.1 & 0.46 & 1.13 & 0.12
\end{tabular}

Reaction conditions: for $160^{\circ} \mathrm{C}$ reaction $[\mathrm{Co}]=33 \mathrm{mM},[\mathrm{Mn}]=1.0 \mathrm{mM},[\mathrm{Br}]=33 \mathrm{mM}$; for $191{ }^{\circ} \mathrm{C}$ reaction $[\mathrm{Co}]=[\mathrm{Mn}]=[\mathrm{Br}]=5.5 \mathrm{mM} ; V_{\mathrm{L}}=$ $35 \mathrm{~mL}, 1.6 \mathrm{~mL} p$-xylene added at $0.08 \mathrm{~mL} / \mathrm{min}, t=0.5 \mathrm{hr}, n=1200 \mathrm{rpm}$. The conversion of $p$-xylene is above $99 \%$ in all the reactions. In addition to 4-CBA and PTA, a few other byproducts were detected in small amounts during the HPLC analysis. These compounds were not identified.
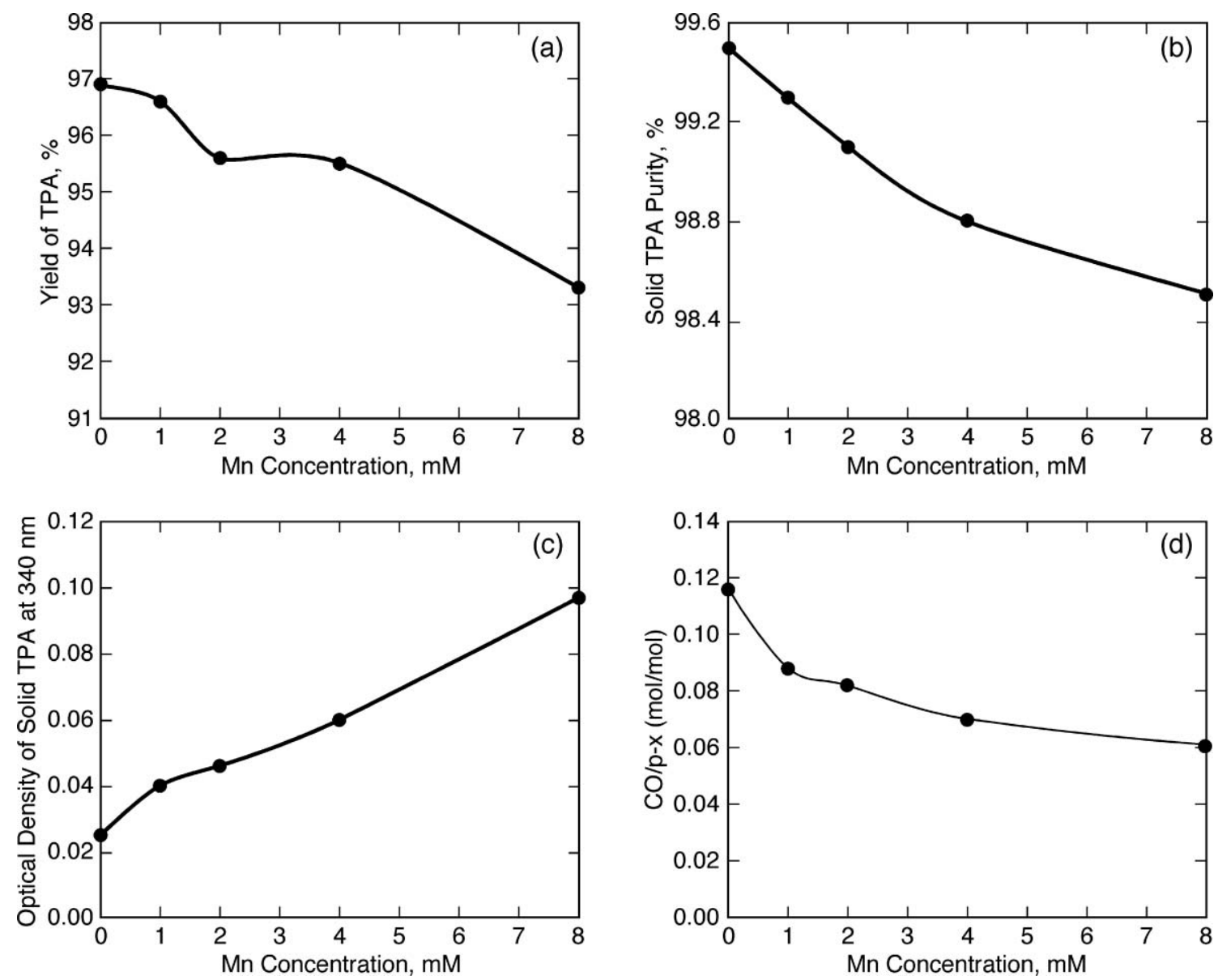

Fig. 6 Effects of manganese concentration on $p$-xylene oxidation. Reaction conditions: $\mathrm{PCO}_{2}=\mathrm{PO}_{2}=30 \mathrm{bar}, T=170{ }^{\circ} \mathrm{C},[\mathrm{Co}]=66 \mathrm{mM}$, $[\mathrm{Br}]=$ $33 \mathrm{mM}, V_{\mathrm{L}}=35 \mathrm{~mL}, 1.6 \mathrm{~mL} p$-xylene added at $0.08 \mathrm{~mL} / \mathrm{min}, t=0.5 \mathrm{hr}, n=1200 \mathrm{rpm}$.

operated by industry. As the data in Table 2 reveal, the reactions yield 2-3 times as much $\mathrm{CO}_{2}$ as $\mathrm{CO}$, regardless of the kind of inert gas present during reaction. This is in good agreement with the previous report that the $\mathrm{CO}_{2} / \mathrm{CO}$ mole ratio is around $3 .^{32}$ Remarkably, the use of $\mathrm{CO}_{2}$ can suppress not only the production of $\mathrm{CO}$, but also the production of $\mathrm{CO}_{2}$ at $160{ }^{\circ} \mathrm{C}$, and it is interesting to note that the yield of $\mathrm{CO}$ is reduced to a larger extent. As a result, the burn rate is 0.14 for $\mathrm{N}_{2}$ and 0.11 for $\mathrm{CO}_{2}$ when $\mathrm{O}_{2}$ pressure is $45 \mathrm{bar}$, and 0.095 for $\mathrm{N}_{2}$ and 0.075 for $\mathrm{CO}_{2}$ when $\mathrm{O}_{2}$ pressure is 12 bar. In both cases, the burning is reduced by $c a .20 \%$ when compared to $\mathrm{N}_{2}$ with similar yields ( $c a .95 \%$ ) of TPA. Also, the yield of TPA is much better with $\mathrm{CO}_{2}$ at $191{ }^{\circ} \mathrm{C}$, suggesting the positive effect of overcoming the kinetic barrier. While the yield of CO is nearly indistinguishable, the yield of $\mathrm{CO}_{2}$ is increased markedly at the higher temperature. Consequently, the reactions should be performed at lower temperature and higher $\mathrm{CO}_{2}$ pressure to inhibit solvent burning.

The formation of $\mathrm{CO}_{x}\left(\mathrm{CO}\right.$ plus $\left.\mathrm{CO}_{2}\right)$ during the $\mathrm{MC}$ process involves a very complicated reaction mechanism. Apart from the solvent burning that is the major source of $\mathrm{CO}_{x}, \mathrm{CO}_{x}$ can also be produced by the over-oxidation of $p$-xylene and the decomposition of the TPA product. These mechanisms are currently under investigation. From the point of view of thermodynamics, it seems plausible that the equilibrium shifts 
to the left upon the addition of a large excess of $\mathrm{CO}_{2}$. In addition, we also observed that the $\mathrm{CO}_{2}$ yield is decreased by adding an appropriate amount of water, another by-product of burning. This also suggests the leftward shift of the equilibrium.

\section{Conclusion}

In summary, we have studied the $\mathrm{Co} / \mathrm{Mn} / \mathrm{Br}$ catalyzed mediumhigh temperature oxidation of $p$-xylene to terephthalic acid in $\mathrm{CO}_{2}$-expanded acetic acid based on the measurement of solvent expansion in a Jerguson cell that is equipped with a high temperature oven. The reactions have been optimized by varying the reaction temperature, the concentration of cobalt and manganese and the use of co-catalyst zirconium. As compared with $\mathrm{N}_{2} / \mathrm{O}_{2}$, the use of $\mathrm{CO}_{2} / \mathrm{O}_{2}$ at sufficiently high inert gas pressure and $160^{\circ} \mathrm{C}$ significantly improved the catalytic performance by decreasing the yield of 4-carboxybenzaldehyde, $p$-toluic acid and other sources of yellow colored by-products. In addition, the quality of solid TPA is also greatly increased due to the reduction of the concentration of the by-products, especially 4-carboxybenzaldehyde. More worthy of mention is that solvent decomposition can also be effectively inhibited with $\mathrm{CO}_{2}$, as confirmed by isotopic experiments, which adds greater value to the $\mathrm{CO}_{2}$-expanded solvents. These results, as an extension of our previous work on the remarkable $\mathrm{CO}_{2}$ effect on $\mathrm{Co} / \mathrm{Zr}$ catalytic system, further support the feasible and promising industrial application of CXLs in this kind of important oxidation reaction. The use of high pressure $\mathrm{CO}_{2}$ as reaction medium requires compression power and this could nullify the energy gain made by operating at lower temperatures. However, with the ever-growing global sentiment towards reduction of carbon emissions, novel solutions such as the one discussed here would be needed to meet government regulations on such emissions and thereby make carbon-emitting processes economically viable.

\section{Acknowledgements}

This work was supported by the National Science Foundation Engineering Research Centers Program, Grant EEC-0310689. We are particularly grateful for the valuable discussions with Drs. Peter Metelski, Wayne Schammel and David Sikkenga of BP, Naperville, IL. We would also like to thank Dr. Todd Williams of the University of Kansas for his kind help with MS analysis.

\section{Notes and references}

1 W. Partenheimer, Catal. Today, 1995, 23, 69-158.
2 P. Raghavendrachar and S. Ramachandran, Ind. Eng. Chem. Res., 1992, 31, 453-462.

3 H. Milan, A. G. Hussain and R. Roberto, US Pat., 20080293964.

4 P. A. Hamley, T. Ilkenhans, J. M. Webster, E. Garcia-Verdugo, E. Vernardou, M. J. Clarke, R. Auerbach, W. B. Thomas, K. Whiston and M. Poliakoff, Green Chem., 2002, 4, 235-238.

5 J. B. Dunn and P. E. Savage, Environ. Sci. Technol., 2005, 39, $5427-$ 5435.

6 Y. S. Chen, J. L. Fulton and W. Partenheimer, J. Am. Chem. Soc., 2005, 127, 14085-14093.

7 P. Jessop and B. Subramaniam, Chem. Rev., 2006, 107, 26662694.

8 T. Seki and A. Baiker, Chem. Rev., 2009, 109, 2409-2454.

9 C. A. Eckert, D. Bush, J. S. Brown and C. L. Liotta, Ind. Eng. Chem. Res., 2000, 39, 4615-4621.

10 C. A. Eckert, C. L. Liotta, D. Bush, J. S. Brown and J. P. Hallett, J. Phys. Chem. B, 2004, 108, 18108-18118.

11 G. T. Musie, M. Wei, B. Subramaniam and D. H. Busch, Coord. Chem. Rev., 2001, 219, 789-820.

$12 \mathrm{M}$. Wei, G. T. Musie, D. H. Busch and B. Subramaniam, J. Am. Chem. Soc., 2002, 124, 2513-2517.

13 M. Wei, G. T. Musie, D. H. Busch and B. Subramaniam, Green Chem., 2004, 6, 387-394.

14 X. Zuo, B. Subramaniam and D. H. Busch, Ind. Eng. Chem. Res., 2008, 47, 546-552.

15 M. A. Zeitlin and D. Wilger-Nowicki, US Pat., 5095 146, 1992.

16 H. Jin, B. Subramaniam, A. Ghosh and J. Tunge, AIChE J., 2006, 52, 2575-2581.

17 B. Rajagopalan, M. Wei, G. T. Musie, B. Subramaniam and D. H. Busch, Ind. Eng. Chem. Res., 2003, 42, 6505-6510.

18 D. R. Burri, K. W. Jun, J. S. Yoo, C. W. Lee and S. E. Park, Catal. Lett., 2002, 81, 169-173.

19 J. S. Yoo, S. H. Jhung, K. H. Lee and Y. S. Park, Appl. Catal. A-Gen., 2002, 223, 239-251.

20 S. E. Park, J. S. Chang and K. W. Lee, Stud. Surf. Sci. Catal., 2004, 153, 303-314.

21 P. Roffia, P. Calini and L. Motta, Ind. Eng. Chem. Prod. Res. Dev., 1984, 23, 629-634.

22 Personal Communication, BP Personnel (names provided in the acknowledgement section), 2007.

23 G. G. Lavoie, R. T. Hembre, C. E. J. Sumner, J. N. Bays, D. B. Compton, B. A. Tennant, B. W. Davenport, D. Lange and T. R. Floyd, PCT Int. Appl. 2006, WO 2006096312.

24 S. H. Jhung and Y. S. Park, Bull. Korean Chem. Soc., 2002, 23, 369 373.

25 A. W. Chester, E. J. Y. Scott and P. S. Landis, J. Catal., 1977, 46, 308-319.

26 R. L. June, M. W. Potter, E. J. Simpson and C. L. Edwards, US Pat., $6153790,2000$.

27 W. Partenheimer, J. Mol. Catal. A-Chem., 2003, 206, 105-119.

28 W. Partenheimer, US Pat., 4992 580, 1991.

29 B. Rajagopalan, Ph.D. Thesis, University of Kansas, 2007.

30 W. Partenheimer, in Catalysis of Organic Reactions, ed. D. W. Blackburn, Marcel Dekker, New York, 1990, pp. 321-346.

31 P. D. Metelski and J. H. Espenson, PCT Int. Appl. 2005, WO 2005000779.

32 Y. Cheng, L. Zhang, G. Xie and X. Li, Chem. React. Eng. Technol. (China), 2003, 19, 182-187. 